\title{
Forest Response to Catastrophic Wind: Results from an Experimental Hurricane
}

\section{Citation}

Cooper-Ellis, Sarah, David R. Foster, Gary Carlton, and Ann Lezberg. 1999. Forest Response to Catastrophic Wind: Results from an Experimental Hurricane. Ecology 80, no. 8: 2683. doi:10.2307/177250.

\section{Published Version}

doi:http:10.2307/177250

\section{Permanent link}

http://nrs.harvard.edu/urn-3:HUL.InstRepos:29394997

\section{Terms of Use}

This article was downloaded from Harvard University's DASH repository, and is made available under the terms and conditions applicable to Other Posted Material, as set forth at http:// nrs.harvard.edu/urn-3:HUL.InstRepos:dash.current.terms-of-use\#LAA

\section{Share Your Story}

The Harvard community has made this article openly available.

Please share how this access benefits you. Submit a story.

\section{Accessibility}




\title{
FOREST RESPONSE TO CATASTROPHIC WIND: RESULTS FROM AN EXPERIMENTAL HURRICANE
}

\author{
Sarah Cooper-Ellis, ${ }^{1}$ David R. Foster, $, 1,4$ Gary Carlton, ${ }^{2}$ And Ann Lezberg ${ }^{3}$ \\ ${ }^{1}$ Harvard Forest, Harvard University, P.O. Box 68, Petersham, Massachusetts 01366 USA \\ ${ }^{2}$ Biological Sciences Department, California State Polytechnic University, Pomona, California 91768 USA \\ ${ }^{3}$ University of Washington, College of Forest Resources, Box 352100, Seattle, Washington 98195-2100 USA
}

Abstract. Infrequent, intense wind disturbance is an important factor in northeastern U.S. forests, yet little is known about the early stages of vegetation reorganization, or the processes that facilitate biotic regulation of ecosystem function after such storms. We designed an experiment, based on a simulated hurricane blowdown, to examine the relationship of tree damage patterns to mortality and regeneration, community dynamics, vegetation recovery, and ecosystem processes. In October 1990, selected canopy trees in a 50 $\times 160 \mathrm{~m}$ area within a 75-yr-old Quercus rubra-Acer rubrum forest in central Massachusetts were pulled over by a winch, using records from the 1938 hurricane to determine the number of trees and direction of fall. The resulting damage to $65 \%$ of trees closely approximated effects of the 1938 storm on New England forests. Damage and mortality varied by tree species and size, indicating the importance of pre-disturbance forest structure and composition in determining the range and severity of impact. Measurements of vegetation and environment in the experimental area and control indicated that, although the manipulated stand sustained dramatic damage and structural reorganization, resilience of trees and understory vegetation provided tight biotic control of ecosystem processes, including nutrient cycling. Continued leaf-out and induced sprouting by damaged trees, increased growth by saplings and understory plants, and seedling establishment on disturbed microsites stabilized the microenvironment. Our findings are in contrast to studies of disturbances in which mortality was higher when damaged trees were removed from the site. This suggests that salvage logging following wind disturbance may have serious long-term implications.

Key words: blowdown, simulated; forest composition and structure; forest dynamics, long term; hurricanes; New England; regeneration; salvage logging; temperate forests; wind disturbance.

\section{INTRODUCTION}

Recognition of the importance of intense wind disturbances in controlling forest landscape patterns has led to considerable research on storm meteorology, patterns of wind impacts, and resulting community dynamics (Peterson and Pickett 1991, Foster 1988a, b, Foster et al. 1999, Webb 1999). Recent studies of tropical storms in the northeastern United States have refined our understanding of the hurricane disturbance regime (Boose et al. 1994, Foster and Boose 1994), factors controlling damage patterns (Foster 1988a, Foster and Boose 1992), and long-term forest dynamics (Hibbs 1983, Foster 1988b, Merrens and Peart 1992). Despite similar advances elsewhere (Walker et al. 1992, Boucher et al. 1994, Bellingham et al. 1995, Peterson and Pickett 1995, Everham and Brokaw 1996, Foster et al. 1999, Webb 1999), the infrequent, unanticipated, and often substantial impacts of intense storms make it difficult to undertake integrated and long-term assessments of environmental, vegetational, and ecosys-

Manuscript received 22 December 1997; revised 25 August 1998; accepted 19 October 1998; final version received 23 December 1998.

${ }^{4}$ Address correspondence to this author. tem responses. In particular, we remain ignorant about the initial stages of vegetation reorganization in relation to specific types of forest damage and changes in resource availability, and about the influence of initial vegetation reorganization on ecosystem processes and long-term vegetation dynamics (Carlton and Bazzaz 1998a, b. Bazzaz 1996).

To provide the relatively controlled conditions necessary for such integrated study of forest disturbance, the Harvard Forest Long Term Ecological Research program designed an experimental hurricane manipulation, based on studies of the 1938 New England hurricane, to simulate the impacts of severe wind damage on an upland forest. This manipulation was developed as part of a broad effort to assess forest response to natural disturbance and anthropogenic stress (Foster et al. 1997). The experimental approach allowed us to establish a true control site; to document baseline conditions before and immediately following the impact; to coordinate studies of the microenvironment (Carlton and Bazzaz 1998a), plant physiological performance (Carlton and Bazzaz 1998b), forest recovery, and ecosystem function (Bowden et al. 1993); and to compare these results with studies of historical hurricanes (Fos- 


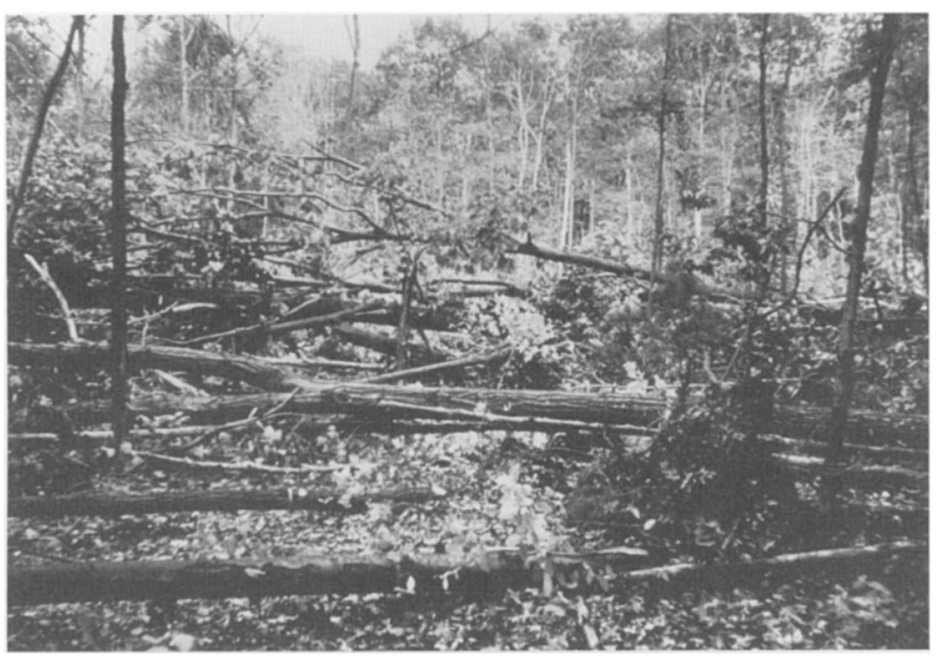

Plate 1. View of the experimental blowdown immediately following completion of the manipulation.

ter and Boose 1992, Boose et al. 1994) and other disturbance processes (Foster et. al. 1997, Magill et al. 1997).

Biogeochemical studies of the hurricane manipulation yielded surprising results that provided additional focus to our study of vegetation recovery (Bowden et al. 1993). Despite a dramatic change in forest structure and $50 \%$ reduction in basal area, nutrient retention rates remained extremely high, fluxes of important trace gases such as $\mathrm{CH}_{2}, \mathrm{NO}_{2}$, and $\mathrm{CO}_{2}$, were essentially unchanged, and there was little change in the soil environment (Plate 1; Bowden et al. 1993, Carlton 1993). The forest exhibited remarkable resilience to a visually catastrophic event and maintained tight biotic control over ecosystem processes, despite major structural damage (Bowden et al. 1993, Foster et al. 1997).

Consequently, our study was designed to evaluate the immediate impact and early stages of community reorganization that influence long-term forest development and facilitate biotic regulation of ecosystem processes (Bormann and Likens 1979, Pacala et al. 1996). Specific objectives included documenting the: (1) types of damage and patterns of mortality among tree species, (2) changes in canopy and forest floor structure, (3) changes in understory diversity and composition, (4) importance of different modes of tree regeneration in controlling changes in species composition and abundance, and (5) relationships of these dynamics to the observed ecosystem resilience. The long-term goal is to integrate experimental and historical findings in an understanding of forest ecosystem response to wind damage that can inform management policy regarding wind damage (cf. Barten et al. 1998).

\section{STUDY AREA}

The Harvard Forest in north-central Massachusetts lies in the New England Upland physiographic region and is characterized by moderate local relief, ranging from $120 \mathrm{~m}$ to $410 \mathrm{~m}$ a.s.l. The climate is cool tem- perate (July mean $20^{\circ} \mathrm{C}$, January mean $-7^{\circ} \mathrm{C}$ ), with average precipitation of $110 \mathrm{~cm}$ distributed evenly throughout the year (Spurr 1957). Soils are moderately well-drained stony loams derived from glacial till overlying schist bedrock on a gentle northwest slope (Simmons 1939-1940, Zen 1983). A discontinuous hardpan at $\sim 60 \mathrm{~cm}$ depth inhibits root penetration and impedes drainage (Lyford et al. 1963). The 75-yr-old Quercus rubra-Acer rubrum forest was selected for the experiment due to its relative homogeneity and similarity to second-growth forests that developed across the region following agriculture and natural reforestation (Lyford et al. 1963).

\section{Methods}

\section{Study area establishment and tree mapping}

The $50 \times 160 \mathrm{~m}$ experimental area and $50 \times 120 \mathrm{~m}$ control area were sited with long axes oriented approximately west to east and separated by a $30-\mathrm{m}$ buffer of similar, untreated forest. The entire area was surveyed in a $10-\mathrm{m}$ grid, and all trees $\geq 5 \mathrm{~cm} \mathrm{dbh}$ (manipulation, 888 trees; control, 776 trees) were mapped to a $10-\mathrm{cm}$ accuracy using a least squares technique (Boose et al. 1998). Trees were tagged and species, dbh, canopy position, and condition were recorded. In order to sample across the light gradient that exists in forest openings at northern latitudes (Canham 1988), $242 \times 5 \mathrm{~m}$ plots were randomly established on each of three E-W transects in the experimental area and on one transect in the control, for a total of $962 \times 5 \mathrm{~m}$ plots.

\section{Experiment design and manipulation}

To mimic damage from the 1938 hurricane, when $\sim 80 \%$ of canopy hardwood trees and all canopy Pinus strobus were damaged in mature stands, data on species, height, and damage in comparable stands in 1938 were used to determine which trees to pull down, by size, species, and direction (Rowlands 1941, Foster 
TABLE 1. Tree density and basal area in the hurricane manipulation before (1990) and after (1993, 1996) the manipulation, and in the control in 1991, 1993, and 1996 based on a census of all trees, including bent, leaning, and snapped trees still living after the experiment.

\begin{tabular}{|c|c|c|c|c|c|c|c|c|c|c|c|c|}
\hline \multirow[b]{3}{*}{ Species } & \multicolumn{6}{|c|}{ Experiment } & \multicolumn{6}{|c|}{ Control§ } \\
\hline & \multicolumn{3}{|c|}{ Density (\%) } & \multicolumn{3}{|c|}{ Basal area $(\%)$} & \multicolumn{3}{|c|}{ Density (\%) } & \multicolumn{3}{|c|}{ Basal area $(\%)$} \\
\hline & 1990 & 1993 & 1996 & 1990 & 1993 & 1996 & 1991 & 1993 & 1996 & 1991 & 1993 & 1996 \\
\hline Acer rubrum & 51.77 & 53.08 & 26.98 & 13.45 & 26.44 & 18.73 & 57.59 & 56.71 & 55.34 & 17.15 & 16.60 & 15.43 \\
\hline Acer saccharum & 2.31 & 3.55 & 1.98 & 0.68 & 1.48 & 1.20 & 0.95 & 1.02 & 1.07 & 0.31 & 0.31 & 0.32 \\
\hline Betula alleghaniensis & 4.21 & 5.92 & 19.77 & 1.58 & 3.12 & 6.51 & 0.16 & 0.17 & 0.18 & 0.07 & 0.07 & 0.06 \\
\hline Betula lenta & 5.16 & 7.11 & 16.39 & 2.95 & 4.52 & 6.96 & 5.22 & 5.43 & 5.34 & 2.45 & 2.46 & 2.38 \\
\hline Betula papyrifera & 3.53 & 2.37 & 0.76 & 5.79 & 4.68 & 2.97 & 1.90 & 2.04 & 1.96 & 2.65 & 2.70 & 2.47 \\
\hline Carya glabralC. ovata & 2.31 & 3.79 & 2.75 & 0.79 & 1.72 & 1.07 & 4.27 & 4.58 & 4.80 & 1.94 & 1.98 & 1.93 \\
\hline Fagus grandifolia & 0.68 & 1.18 & 2.30 & 0.32 & 0.74 & 2.80 & 0.00 & 0.00 & 0.00 & 0.00 & 0.00 & 0.00 \\
\hline Fraxinus americana & 6.39 & 6.40 & 1.06 & 5.11 & 5.09 & 1.58 & 4.75 & 4.07 & 4.27 & 3.23 & 2.91 & 2.82 \\
\hline Ostrya virginiana & 1.22 & 2.13 & 0.76 & 0.14 & 0.33 & 0.32 & 0.00 & 0.00 & 0.00 & 0.00 & 0.00 & 0.00 \\
\hline Pinus strobus & 3.13 & 2.84 & 9.81 & 2.30 & 1.15 & 4.28 & 2.69 & 2.38 & 2.49 & 1.97 & 1.87 & 1.77 \\
\hline Quercus rubra & 19.02 & 11.37 & 5.62 & 66.80 & 50.74 & 51.37 & 21.99 & 23.09 & 24.02 & 70.15 & 71.03 & 72.53 \\
\hline Other $\dagger$ & 0.27 & 0.24 & 11.82 & 0.07 & 0.00 & 2.23 & 0.47 & 0.51 & 0.53 & 0.07 & 0.07 & 0.29 \\
\hline Total (absolute values) & 920 & 489 & 823 & 27.8 & 12.4 & 11.2 & 1053 & 982 & 937 & 29.4 & 28.9 & 31.6 \\
\hline
\end{tabular}

$\dagger$ Castanea dentata, Prunus serotina, Tilia americana, and Tsuga canadensis.

\$ Absolute density is no. stems/ha; absolute basal area is in $\mathrm{m}^{2} / \mathrm{ha}$.

$\S$ The decline in density and basal area in the control is the result of winter storm damage in forests throughout the region in December 1992.

1988a). Based on a preliminary experiment (Carlton 1993, D. Foster, unpublished data), we anticipated that pulled trees would account for $<40 \%$ of total damage, with the remaining damage caused indirectly to trees in the path of fall. Using this information, we randomly selected a subset of canopy trees to be pulled.

In early October 1990, during peak hurricane season, canopy trees were individually pulled toward the northwest. A cable was attached to tree trunks at $\sim 6 \mathrm{~m}$ height and force was applied by winch from outside the study area until the roots or bole failed and the mass of the crown forced the tree over. Trees closest to the winch were pulled first. Trees were not pulled beyond their initial point of repose and trees indirectly damaged by falling trees were left where they fell. No machinery was used in the study area; all plant and soil disturbance was a consequence of pulling, treefall, or uprooting.

Assessment of forest structure, tree damage, and soil disturbance

In winter 1990-1991, all damaged trees in the manipulated area were classified as: bent, leaning, snapped, or uprooted. Spatial and structural changes in the vegetation were assessed on detailed site maps, including damage type, compass orientation, length and height above ground of fallen or damaged boles, height of snap or bending apex, and crown location. Dimensions of mounds (width, length, height) and pits (width, length, depth) created by uprooted stems were measured and mapped, and the mound area was approximated as an ellipse. Linear regression was used to relate mound dimensions to tree diameter.

\section{Tree survival, sprouting, and regeneration}

In both areas, trees were remeasured for diameter and assessed for degree of crown survival and for pres- ence (in 1991), numbers (in 1992, 1993, 1994, and 1995), and location (basal, trunk, or branch) of sprouts. Logistic regression (LOGIT, Steinberg and Colla 1991) was used with categorical (species, prior condition, damage type) and continuous (dbh, grid position) variables to evaluate factors associated with sprouting and leafing-out. Likelihood ratio tests were used with a Bonferroni adjustment (Rice 1989). Within each $2 \times$ $5 \mathrm{~m}$ plot, all sapling-sized individuals $(>30 \mathrm{~cm}$ tall, $<5 \mathrm{~cm} \mathrm{dbh}$ ) were tagged and measured (height, basal and bole diameters) in 1990 and in years 3 and 6 .

\section{Understory vegetation}

The understory was assessed before (1990) and after $(1991,1992,1995)$ the manipulation in the $9610-\mathrm{m}^{2}$ $(2 \times 5 \mathrm{~m})$ plots (shrubs) and in nested circular $1-\mathrm{m}^{2}$ plots (herbs). Cover values and $95 \%$ confidence intervals were calculated for each species for all plots and total cover of life-forms (saplings $>30 \mathrm{~cm}$ in height and $<5 \mathrm{~cm}$ dbh, seedlings $(<30 \mathrm{~cm}$ tall), shrubs $>1$ $\mathrm{m}$, shrubs $<1 \mathrm{~m}$, ferns, herbs/graminoids, club moss, and moss) was estimated. Average species richness of herbs, ferns, club moss, and graminoids was calculated per plot and per transect by year.

\section{RESULTS}

\section{Changes in canopy and forest floor structure}

Before the manipulation, both areas were structurally and compositionally similar and were dominated in basal area by Quercus rubra and in density by Acer rubrum (Table 1). The upper canopy consisted of 20-30 $\mathrm{m}$ tall $Q$. rubra, A. rubrum, Betula papyrifera, Fraxinus americana, Carya glabra, and $C$. ovata, with a lower stratum of A. rubrum, Betula lenta, B. alleghaniensis, and Pinus strobus. The year after manipulation, $32.4 \%$ 


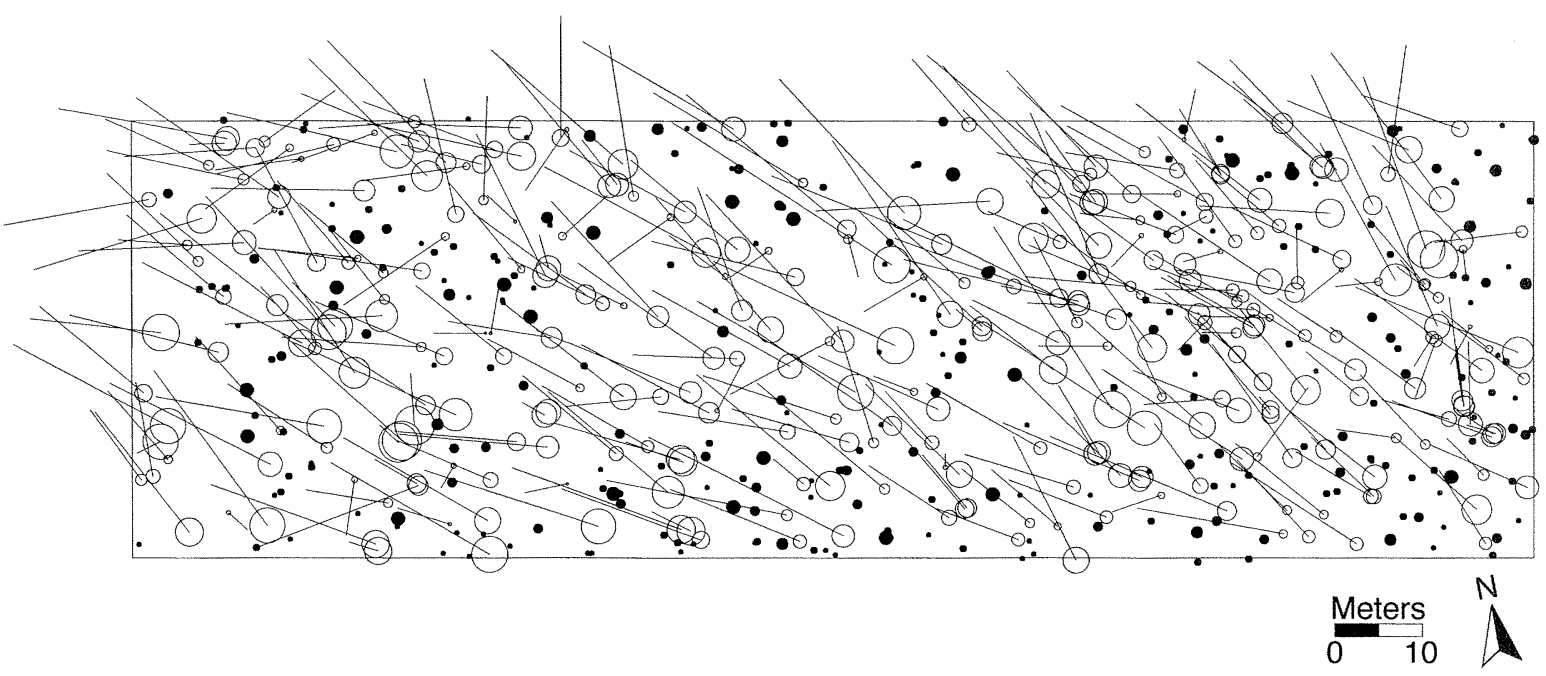

FIG. 1. Map of standing trees (solid circles) and uprooted tree stems (open circles) on the experimental area showing orientation and approximate length of boles and mound dimensions. Median orientation for uprooted stems was 294 degrees. Circles representing trees are sized relative to diameter in five size classes.

of trees $>5 \mathrm{~cm}$ dbh remained standing and undamaged in the experimental area, as compared to $99.3 \%$ in the control. In the experimental area, basal area of live, upright trees including those with damaged, but still leafing, crowns decreased by $50 \%$, average nearest distance between standing trees increased from $3.3 \mathrm{~m}$ to $7.8 \mathrm{~m}$, and maximum distance increased from $7.6 \mathrm{~m}$ to $20.9 \mathrm{~m}$.

The uprooting, snapping, and bending during the manipulation displaced $82.3 \%$ of canopy trees and $65 \%$ of all trees $>5 \mathrm{~cm}$ dbh from vertical. However, $>80 \%$ of damaged trees survived and re-leafed in the first growing season. Consequently, the manipulation redistributed the canopy from a continuous layer 20-30 $\mathrm{m}$ tall to a highly uneven structure, with most foliage concentrated only a few meters above the ground. A wide range of debris types and microsites was created. The distribution of mounds, pits, and downed boles and crowns was heterogeneous (Fig. 1). Uprooted boles covered $12.8 \%$ of the ground, and 277 uproot mounds and 264 pits covered $\sim 8.3 \%$. Mound heights ranged from 12 to $290 \mathrm{~cm}$ and pits were $12 \mathrm{~cm}$ to $157 \mathrm{~cm}$ deep. Tree diameter $(D)$ was a good predictor of mound width $(W): W=0.24+0.48 \cdot D ; r^{2}=0.754$, MSE $=$ $0.003, r=250$. Mound height and thickness and pit depth were less strongly correlated with tree diameter.

\section{Tree damage and survival}

Presence and type of damage varied with species (Fig. 2) and size, factors that covary. The majority of uproots were Quercus rubra and Betula papyrifera, which were the largest trees, whereas bent trees were primarily small Carya spp. and Acer rubrum. Across all species, damage increased overall with increasing size up to $15 \mathrm{~cm} \mathrm{dbh}$, and decreased in larger size classes. In general, small stems were bent, larger stems were uprooted, and dead trees were snapped. Indirectly damaged trees tended to bend or snap.

Terminology regarding survival is necessarily complex because basal and trunk (epicormic) sprouts developed on trees with living and dead crowns. We defined "survival" as leafing of the original crown and "mortality" as crown death; all sprouts were counted as new stems. Survival of damaged trees was high in the first year $(86 \%)$. Although survival in year 1 was greatest in larger trees, subsequent mortality in large, uprooted trees produced a significant relationship between diameter and mortality (logistic regression, $P<$ 0.0033 ). Mortality in Quercus rubra was particularly high between years 1 and 3, when survival declined from $90 \%$ to $<50 \%$ (Fig. 3o). Annual mortality for all species increased in years 2 and 3 and levelled off in later years (Fig. 3a). By year 6, only $18 \%$ of damaged trees retained live crowns. Survival varied strongly by species: Acer saccharum $(76 \%)>$ Betula alleghaniensis $(71 \%)>$ B. lenta $(55 \%)>$ Carya spp. $(53 \%)>$ Pinus strobus $(44 \%)>A$. rubrum $(41 \%)>$ Quercus rubra $(29 \%)>$ B. papyrifera $(19 \%)>$ Fraxinus americana $(15 \%)$ (Fig. 3g-o). Survival also varied by damage type over six years: Leaning $(45 \%)>$ Bent $(33 \%)$ $\sim$ Snapped $(32 \%)>$ Uprooted $(8 \%)$ (Figure 3a-f).

\section{Regeneration}

Sapling and sprout density (all stems $<5 \mathrm{~cm}$ dbh and $>30 \mathrm{~cm}$ tall) increased from 5722 stems/ha prior to the manipulation to 24917 in 1993, and then decreased to 20167 in 1996. Basal area of saplings and sprouts increased from $<1 \mathrm{~m}^{2} / \mathrm{ha}$ in 1990 to $>6 \mathrm{~m}^{2} / \mathrm{ha}$ in 1996 , but, proportionally, this represents a change from $1 \%$ to $>40 \%$ of total basal area (Fig. 4). Saplings in the understory before the manipulation (advance regeneration) contributed more basal area than did sprouts, 


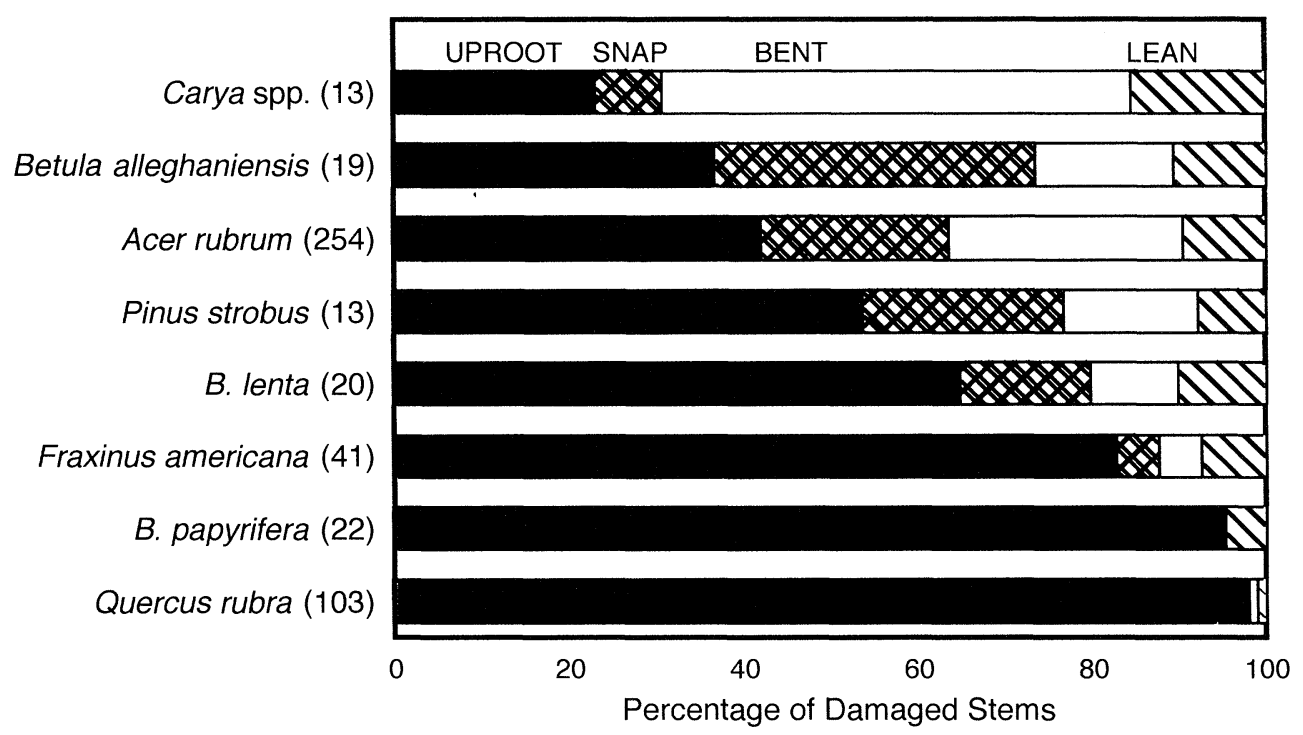

FIG. 2. Distribution of damage types among major species for all damaged stems $>5 \mathrm{~cm}$ dbh. Bars show percentages of each species that were uprooted, snapped, bent, or leaning following the experimental manipulation. Numbers in parentheses indicate the sample size for each species.

and newly established seedlings contributed large numbers but little basal area. Prunus serotina decreased from $\sim 28 \%$ of all saplings in 1990 to $13 \%$ in 1996 , Betula papyrifera saplings, which were not present in 1990 , increased to $\sim 15 \%$ of saplings by 1993 , and Quercus rubra saplings increased from $<1 \%$ to $\sim 5 \%$ (Table 2). In the control, there was no change in saplings or sprouts.

Sprouting increased greatly following the manipulation, as damaged trees developed basal and trunk sprouts and the increased light stimulated epicormic sprouting in many undamaged trees (Fig. 3). Sprouting frequency varied by species, size, and damage type, and was most common in Fraxinus americana and Acer rubrum (Fig. 3). Sprouting type varied by tree health prior to the experiment, position on the N-S light gradient in the manipulation, damage type, and species (Table 3). Healthy trees were more likely to produce trunk sprouts than were moribund trees. Bent and snapped trees were more likely to have basal sprouts than were standing or leaning trees (Table 3). Basal sprouting increased from a maximum of 49 sprouts per tree in year 2 to 75 sprouts per tree in year 3 and then sharply decreased to a maximum of 25 in year 4 . In year 3 , there were $>5000$ trunk sprouts/ha.

\section{Arboreal layer dynamics}

By year 3, tree density and basal area in the experimental area declined to $53 \%$ and $45 \%$, respectively (Table 1). In the control, density and basal area declined to $93 \%$ and $98 \%$ as a result of winter storms that damaged the small size classes (J. O'Keefe, unpublished data). By year 6 , sapling recruitment restored tree density in the manipulation to $89 \%$ of original values. As tree mortality decreased from 1993 to 1996 in the experimental area (Fig. 3g-o), and growth rates increased in surviving trees from 1990 to 1996 (Fig. 5), basal area declined only slightly from 1993 to 1996 (Table $1)$. Growth in all species was greater in the manipulation than the control, but especially in Pinus strobus, Acer rubrum, and Betula alleghaniensis/B. lenta (Fig. 5). Overall, compositional changes following the manipulation were minor. Relative basal area of Acer rubrum increased from $14 \%$ to $19 \%$ by 1996 , whereas Quercus rubra decreased from $\sim 67 \%$ to $\sim 51 \%$ (Table 1). Relative density of Betula spp. increased from $13 \%$ to $37 \%$ by 1996 and that of Pinus strobus increased from $3 \%$ to $\sim 10 \%$, whereas Acer rubrum decreased from $\sim 52 \%$ to $27 \%$ and Quercus rubra decreased from $19 \%$ to $\sim 6 \%$ (Table 1 ).

\section{Understory vegetation dynamics}

The manipulation altered the relative abundance of life-forms and forest understory structure. Sapling and shrub cover increased, but only saplings showed significant increases relative to the control (Fig. 6). The early successional shrubs Rubus allegheniensis, Rubus idaeus, and Rhus typhina appeared and increased after the manipulation. Amelanchier sp. and Viburnum cassinoides increased in both height and cover, and dominant Corylus cornuta increased in height (Fig. 7). Herbs showed high variability between years and plots, for example, a decline in cover due to drought in 1991, but little overall change in abundance. Dennstaedtia punctilobula increased by almost $100 \%$ in the manipulation, the largest change in an abundant species.

Richness climbed following the manipulation from 29-37 species per transect to $38-51$ in year 2 , then fell 


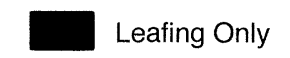

Leafing Only
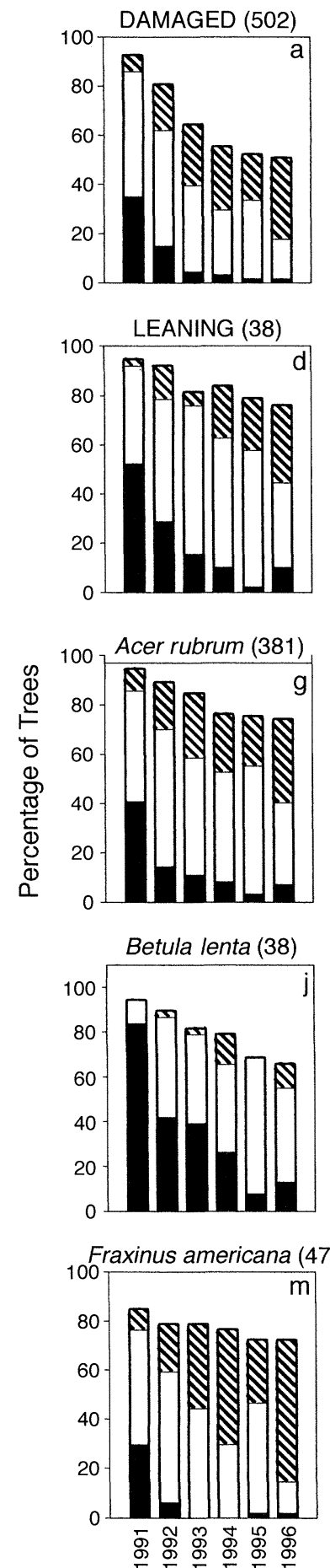
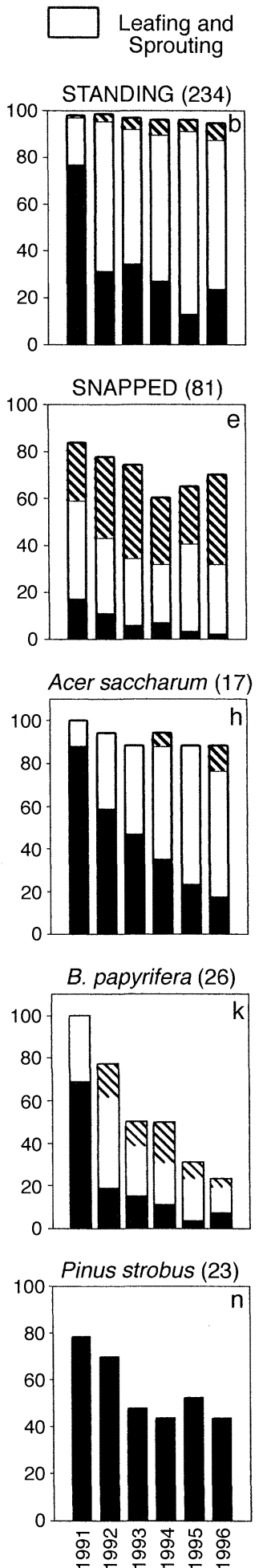

Sprouting Only
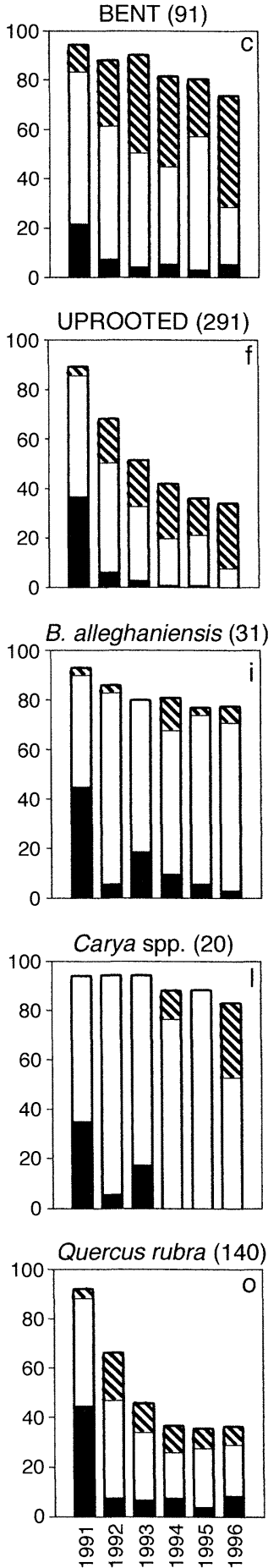

FIG. 3. Survival (re-leafing of canopy) and sprouting of trees (stems $>5 \mathrm{~cm} \mathrm{dbh}$ ) on the experimental area by damage type $(\mathrm{a}-\mathrm{f})$ and species $(\mathrm{g}-\mathrm{O})$. The number of trees in each category is given in parenthesis. 


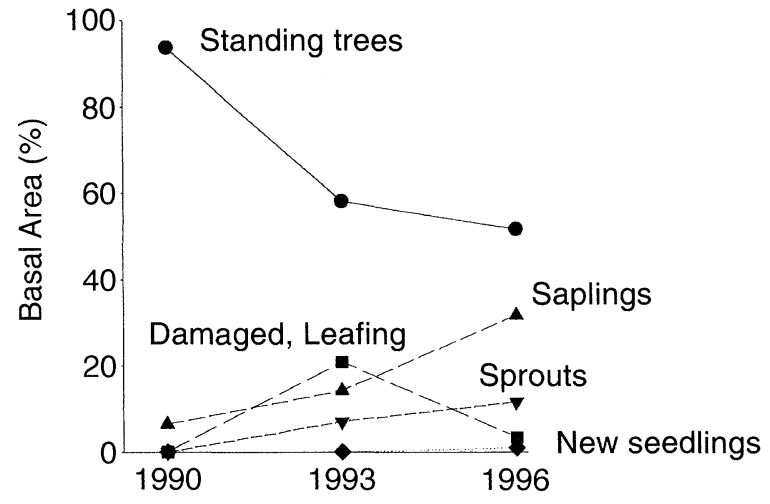

FIG. 4. Percentages of total tree basal area in standing trees, damaged trees, saplings, sprouts, and seedlings before manipulation (1990) and three and six years following the manipulation.

to $35-40$ in year 5, whereas in the control it fluctuated between 32 and 35 species per transect. In the experimental area, there was an increase from 5.2 to 5.9 species per plot, on average; in the control, there was fluctuation between 4.9 and 5.4 species per plot, a statistically insignificant difference. The dynamics of the 23 new species in the experiment and eight species in the control were variable: some were scattered and transient, whereas others such as Epilobium sp., Potentilla simplex, and Rubus spp. persisted or increased in successive years (Table 4). New species were associated with sites disturbed by uprooting: $92 \%$ of the new species established on plots containing a pit or mound, which constituted only $60 \%$ of all plots. One $1-\mathrm{m}^{2}$ herb plot that originally supported only three species contained 11 species after uprooting disturbed $25 \%$ of the soil surface.

\section{Discussion}

\section{Forest recovery from disturbance: the importance of} survival, reiteration, and regeneration

The results of this manipulation highlight a paradox emerging from studies of windstorms and some other natural physical disturbances: despite massive reorganization of physical structure and the appearance of catastrophe, many important ecosystem processes remain intact. In our experiment, the maintenance and rapid recovery of plant cover and development of a low canopy clearly was instrumental in moderating changes in soil environment and maintaining biogeochemical cycles (Bowden et al. 1993). The experimental approach showed the extent and mechanisms of this reorganization and control over microenvironmental conditions.

The hurricane manipulation generated a massive reorganization of biomass, soil disruption, and changes in aboveground environment, and produced a wide array of new and persistent structures in the forest. Standing basal area and tree density declined by $\sim 50 \%$, and average inter-tree distance increased 2.5 times to nearly $8 \mathrm{~m}$. With the majority of canopy trees uprooted, most boles came to rest on or within $25 \mathrm{~cm}$ of the ground, foliage was restructured from a continuous high canopy 20-30 $\mathrm{m}$ tall to a variable distribution concentrated below $5 \mathrm{~m}$, and large mound and pit complexes covered $8 \%$ of the forest floor. The creation of distinctive soil microsites such as pits and mounds exerted strong con-

TABLE 2. Logistic regression results for tree responses in the third year following manipulation.

\begin{tabular}{|c|c|c|c|}
\hline Tree response & Significant predictors $†$ & $\begin{array}{l}\text { Percentage } \\
\text { of trees } \ddagger\end{array}$ & $G$ \\
\hline Leafout & $\begin{array}{l}\text { Damage }^{c} \text { Species }^{c} \\
\quad \text { Stand }>\text { Lean }>\text { Bent }>\text { Uproot }>\text { Snap } \\
\text { Carya }>\text { Beal }>\text { Bele }>\text { Acru }>\text { Fram }>\text { Bepa }>\text { Qubo }\end{array}$ & 54.8 & 297.2 \\
\hline Trunk sprouts & $\begin{array}{l}\text { Cond }^{\mathrm{c}}, \mathrm{S}-\mathrm{N} \text { coordinate }(+)^{\mathrm{b}}, \text { Damage }^{\mathrm{a}} \text {, } \text { Species }^{\mathrm{a}} \\
\text { Live }>\text { Moribund } \\
\text { Lean }>\text { Bent }>\text { Stand }>\text { Snap }>\text { Uproot } \\
\text { Carya }>\text { Fram }>\text { Acru }>\text { Beal } \sim \text { Bele }>\text { Bepa }>\text { Qubo }\end{array}$ & 47.6 & 116.6 \\
\hline Basal sprouts & $\begin{array}{l}\text { Damage }^{\mathrm{c}}, \mathrm{S}-\mathrm{N} \text { coordinate }(+)^{\mathrm{b}} \\
\quad \text { Bent }>\text { Snap }>\text { Lean }>\text { Uproot } \sim \text { Stand }\end{array}$ & 38.2 & 127.3 \\
\hline Leaves and sprouts & $\begin{array}{l}\text { Damage }^{c}, \text { Species }^{\mathrm{c}}, \text { Cond }^{\mathrm{a}}, \mathrm{S}-\mathrm{N} \text { coordinate }(+)^{\mathrm{a}} \\
\text { Stand } \gg \text { Bent }>\text { Lean }>\text { Snap }>\text { Uproot } \\
\text { Carya }>\text { Fram } \sim \text { Acru }>\text { Beal } \sim \text { Bepa }>\text { Qubo } \\
\text { Live }>\text { Moribund }\end{array}$ & 74.7 & 253.2 \\
\hline
\end{tabular}

Notes: All of the models were significant at $P \ll 0.00001$. Superscript letters indicate Bonferroni-adjusted significance levels as follows: ${ }^{\text {a }} P<0.0033$; ${ }^{\mathrm{b}} P<0.00033,{ }^{\mathrm{c}} P<0.000033$. Multistate categorical independent variables are coded as binary and are compared to a reference variable, which is indicated in boldface type. These variables are ranked according to the odds ratio, which gives the likelihood of a response as compared to the reference variable. Abbreviations for species rankings are as follows: Carya $=$ Carya spp., Beal $=$ Betula alleghaniensis, Bele $=$ Betula lenta, Acru $=$ Acer rubrum, Fram $=$ Fraxinus americana, Bepa $=$ Betula papyrifera, Qubo $=$ Quercus rubra .

$\uparrow$ Logistic regression analysis (LOGIT; Steinberg and Colla 1991) was used to assess models that included terms for size (dbh), species, damage type, prior tree condition ("Cond": dead, live, or moribund), and tree location (S-N coordinates within study site) tested against the presence or absence of each tree response.

$\ddagger$ Percentage of trees showing the indicated response. Species in minor categories $(<20$ trees $)$ and previously dead trees were excluded. 
TABLE 3. Density and basal area of saplings and sprouts in 1990 (before the manipulation) and in 1993 and 1996.

\begin{tabular}{|c|c|c|c|c|c|c|c|c|}
\hline \multirow[b]{3}{*}{ Species } & \multicolumn{4}{|c|}{1990} & \multicolumn{4}{|c|}{1993} \\
\hline & \multicolumn{2}{|c|}{ Density } & \multicolumn{2}{|c|}{ Basal area } & \multicolumn{2}{|c|}{ Density } & \multicolumn{2}{|c|}{ Basal area } \\
\hline & No. stems/ha & $\%$ & $\mathrm{~m}^{2} / \mathrm{ha}$ & $\%$ & No. stems/ha & $\%$ & $\mathrm{~m}^{2} / \mathrm{ha}$ & $\%$ \\
\hline Acer rubrum & 1083.10 & 18.93 & 0.39 & 42.98 & 5805.56 & 23.30 & 1.42 & 27.02 \\
\hline Betula alleghaniensis/lenta & 1583.33 & 27.67 & 0.20 & 21.60 & 5777.78 & 23.19 & 1.57 & 29.97 \\
\hline Betula papyrifera & 0.00 & 0.00 & 0.00 & 0.00 & 3708.33 & 14.88 & 0.19 & 3.62 \\
\hline Castanea dentata & 152.78 & 2.67 & 0.03 & 3.09 & 388.89 & 1.56 & 0.25 & 4.71 \\
\hline Carya spp. & 0.00 & 0.00 & 0.00 & 0.33 & 625.00 & 2.51 & 0.10 & 1.85 \\
\hline Fraxinus americana & 625.00 & 10.92 & 0.04 & 3.86 & 2986.11 & 11.98 & 0.38 & 7.20 \\
\hline Ostrya virginiana & 111.11 & 1.94 & 0.07 & 7.60 & 555.56 & 2.23 & 0.14 & 2.68 \\
\hline Pinus strobus & 361.11 & 6.31 & 0.13 & 14.77 & 361.11 & 1.45 & 0.43 & 8.20 \\
\hline Prunus pensylvanica & 0.00 & 0.00 & 0.00 & 0.00 & 180.56 & 0.72 & 0.04 & 0.77 \\
\hline Prunus serotina & 1597.22 & 27.91 & 0.04 & 4.74 & 3500.00 & 14.05 & 0.33 & 6.29 \\
\hline Quercus rubra & 27.78 & 0.49 & 0.00 & 0.44 & 611.11 & 2.45 & 0.39 & 7.45 \\
\hline Other $†$ & 180.55 & 3.16 & 0.01 & 0.60 & 416.67 & 1.67 & 0.01 & 0.24 \\
\hline Total & 5722.18 & 100.00 & 0.91 & 100.00 & 24916.67 & 100.00 & 5.24 & 100.00 \\
\hline
\end{tabular}

$\dagger$ Other species include Acer saccharum, Cornus alternifolia, Fagus grandifolia, Populus tremuloides, Quercus alba, Salix sp., Sorbus americana, and Tsuga canadensis.

trol on regeneration patterns (Carlton and Bazzaz 1998b).

Despite this appearance of catastrophe, the ecosystem and compositional responses were muted, apparently as a consequence of the rapid reestablishment of a new forest canopy near the forest floor. Maintenance of canopy cover shaded the ground surface, stabilizing the light, temperature, and hydrological environment, factors that control biogeochemical cycling, trigger seed germination, and encourage regeneration (Carlton and Bazzaz 1998a). Local hot spots (literally) developed where small gaps allowed sunlight to reach the ground, raising soil temperatures. However, such areas contributed a small percentage of the ground surface and thus had little effect on the overall forest response.

Despite the large forest canopy openings and decrease in standing biomass, the vegetation composition changed surprisingly little. In the arboreal layers, there were small increases in Betula lenta, B. alleghaniensis, and Pinus strobus, and a decline in Acer rubrum, $B$. papyrifera, Fraxinus americana, and Quercus rubra. Pits and mounds were focal points for the emergence of seedlings and weedy species with a seed bank strategy, such as Lonicera, Prunus, Rubus, Erechtites, and Epilobium (Livingston and Allessio 1968, Marks 1974, Baskin and Baskin 1996). Distinctive communities characterized by Rubus stems and tussocks of Carex scoparia developed on mounds. Local establishment of 23 new species, many of them transient, led to a shortlived increase in species richness, but there was little change in relative abundance or composition. Similarly, there was little to no overall change in soil temperature and moisture, or biogeochemical processes such as trace gas $\left(\mathrm{CO}_{2}, \mathrm{CH}_{4}, \mathrm{NO}_{2}\right)$ fluxes or net nitrification and mineralization of nitrogen (Bowden et al. 1993, Foster et al. 1997), although areas of disturbed soil such as uproot mounds produced localized high fluxes of trace gases (Bowden et al. 1993). Thus, in- terpreting the biotic responses that enable the maintenance, recovery, and development of the new forest canopy is critical for understanding the paradox between physical damage and muted systemic change.

Although rapid, the recovery of plant cover and development of a new forest canopy was dynamic and highly variable, involving survival of damaged trees and a range of regeneration responses. The contributions of these various processes changed progressively after the manipulation. In terms of biomass dynamics, canopy recovery and reestablishment, and compositional change, the observed patterns from the experimental hurricane diverge markedly from those of many studies and interpretation of vegetation dynamics after physical disturbance (cf. Peterson and Pickett 1995). Gap theory suggests that, as canopy openings increase in size, the importance of seedling establishment increases relative to ingrowth and understory recruitment (Whitmore 1982, Merrens and Peart 1992). To date, despite their high numbers, new seedlings have contributed little to stand basal area or recovery of canopy cover. Instead, re-leafing of damaged and uprooted trees and sprouting, two processes that are seldom considered as important components in vegetation development and biotic recovery, have been critical in the initial reestablishment of a low canopy. In addition to moderation of microenvironmental conditions, this dense foliage has been responsible for inhibiting the growth and development of the seedling layer. Through time, as surviving damaged trees died, sprouting and advanced regeneration became more important; by year 6 , seedling regeneration also contributed to stand basal area.

Immediately following the manipulation, high survival rates $(86 \%)$ and extensive crown re-leafing by damaged trees produced a low, dense canopy during the first growing season. Such high survival was especially surprising, given the great extent of uprooting, 
TABLE 3. Extended.

\begin{tabular}{crrrr}
\hline \hline & \multicolumn{2}{c}{1996} & \multicolumn{2}{c}{ Basal area } \\
\cline { 1 - 2 } \cline { 5 - 5 } \cline { 5 - 5 } Do. stems/ha & \multicolumn{1}{c}{$\%$} & & $\mathrm{~m}^{2} / \mathrm{ha}$ & \multicolumn{1}{c}{$\%$} \\
\hline 4611.11 & 22.87 & & 0.92 & 14.24 \\
4680.56 & 23.21 & & 3.26 & 50.44 \\
2638.89 & 13.09 & & 0.46 & 7.12 \\
263.89 & 1.31 & & 0.17 & 2.63 \\
388.89 & 1.93 & & 0.08 & 1.28 \\
2347.22 & 11.64 & & 0.13 & 2.01 \\
291.67 & 1.45 & & 0.16 & 2.48 \\
777.78 & 3.86 & & 0.86 & 13.31 \\
166.67 & 0.83 & & 0.13 & 2.01 \\
2625.00 & 13.02 & & 0.26 & 4.02 \\
944.44 & 4.68 & & 0.03 & 0.46 \\
430.56 & 2.13 & & 0.08 & 1.30 \\
20166.66 & 100.00 & & 6.46 & 100.00 \\
\hline
\end{tabular}

but the reduced root area in uprooted stems was able to support remarkably large canopies on the prostrate boles of most species. Survival (re-leafing of crowns of damaged trees) was influenced in a complex fashion by three interacting factors: type of damage, stem size, and species. Small, bent, and leaning trees suffered low mortality. Quercus rubra, which was large and uprooted extensively, re-leafed prolifically in the first year, but experienced high mortality in year 2 . In contrast, Betula lenta exhibited higher survival through the subsequent years. As surviving trees and the releafing declined through time, a number of regeneration mechanisms including reiteration of basal and trunk sprouts, upgrowth of advanced regeneration, and seedling establishment, maintained a continuous and growing canopy and brought tree density back nearly to original levels $(89 \%)$. Variation in these regeneration mechanisms by species, stem size, and type of damage make the recovery process strongly dependent on the original vegetation composition and specific damage pattern.

The strong light gradient near the ground induced a differential growth response between the saplings present in the understory at the time of manipulation and the much smaller seedlings that established in the first year after the disturbance. Saplings that reached into the high light conditions above the "canopy" of fallen debris, understory plants, and re-leafing crowns, displayed a marked increase in height and diameter and steadily increased in proportion to total stand basal area over the 6-yr period, to form approximately one-third of stand basal area (Fig. 5). Many of these stems are $<5 \mathrm{~cm} \mathrm{dbh}$ and thus are not included in the totals for basal area and density in Table 1. As these stems continue to cross the 5-cm threshold, however, we expect basal area to begin to recover. The rapid increase in sapling and sprout density from $<6000$ ha to nearly $25000 /$ ha over the first three years, and subsequent decline to $\sim 20000 / \mathrm{ha}$, indicate that the stand is passing through the stem exclusion phase of development and differential growth, and further thinning will increasingly characterize this cohort (Oliver and Larson 1990).

\section{Results in historical perspective}

Many factors determine the relative importance of the mechanisms involved in forest recovery; changes in these factors could easily alter recovery from a particular event. The ability to re-leaf or reiterate varies considerably among species, and initial composition is therefore a critical variable. For example, as a result of New England land use history, extensive areas in the early 20 th century were dominated by Pinus stro-

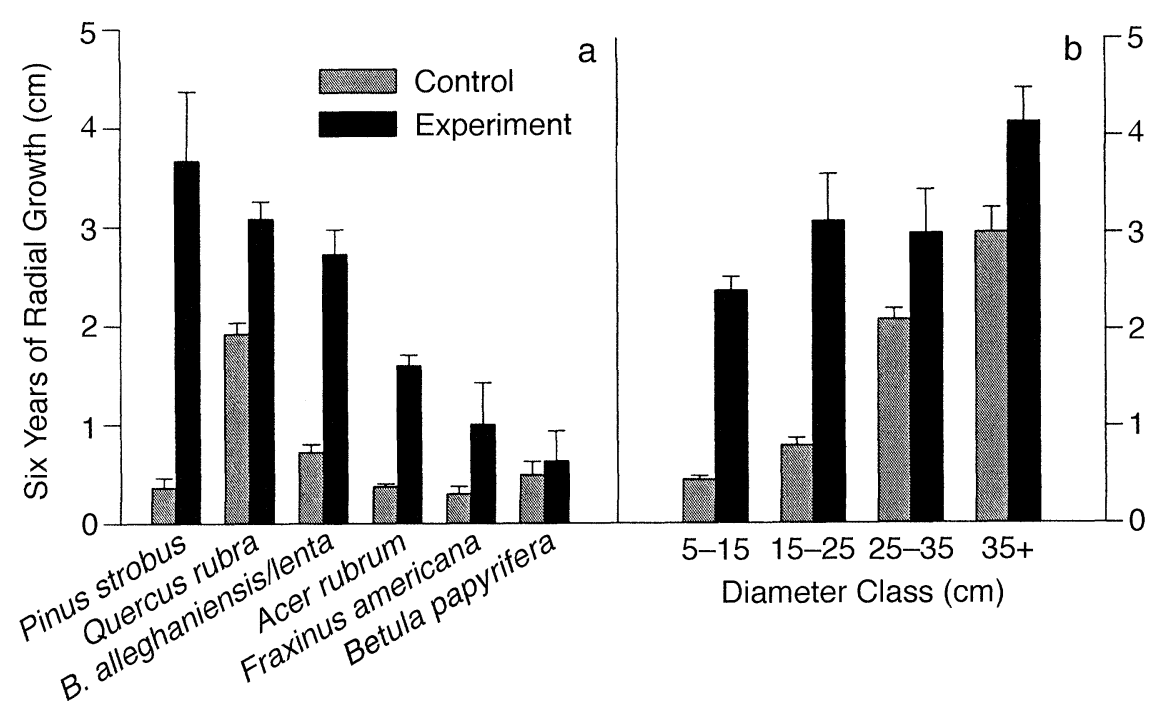

FIG. 5. Average radial growth from 1990 (before the manipulation) to 1996 in the experimental and control areas: (a) with all diameter classes pooled for each species; and (b) with all species pooled for each diameter class by species and tree diameter. Error bars are +1 SE of the mean. 


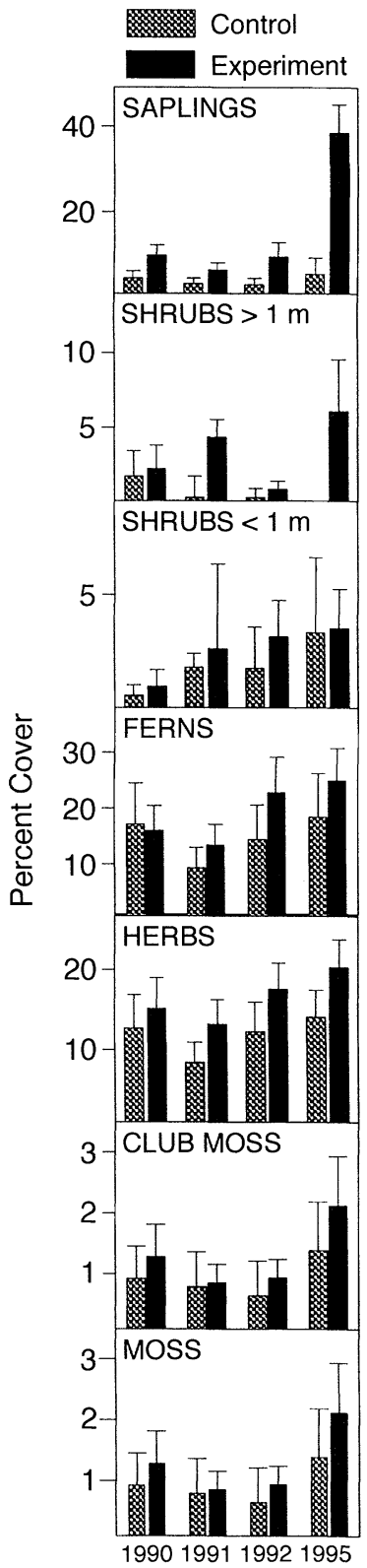

FIG. 6. Average understory cover in the experiment and control plots before $(1990)$ and after $(1991,1992,1995)$ the experiment, by life-form category. Error bars show 95\% confidence intervals.

bus, which preferentially uprooted during the 1938 hurricane (Foster et al. 1997). Lacking the ability to sprout or support a canopy when uprooted, pines were largely replaced by hardwoods that survived, sprouted, or grew from advance regeneration and seedlings (Foster 1988b).

Similarly, the inverse relationship between sprouting ability and size in most species indicates that recovery mechanisms may vary strongly with stand age (Peterson and Carson 1996). Interestingly, in studies of oldgrowth forests, the roles of various types of regener- ation have differed from those reported from this 75yr-old hardwood stand (Dunn et al. 1983, Foster 1988b, Peterson and Pickett 1995, Peterson and Carson 1996). Many northeastern old-growth forests are dominated by Tsuga canadensis, which casts a dense shade that limits the abundance of advance regeneration (Dunwiddie et al. 1996). Uprooted Tsuga canadensis demonstrate little survival after windthrow, and the subsequent forest may consist of distinct age and size cohorts of very different species: older, extremely shadetolerant species (e.g., Tsuga canadensis and Fagus grandifolia) that were present in the original understory, and younger, less shade-tolerant, wind-dispersed species that established after the disturbance (e.g. Betula spp. and Acer rubrum; Foster 1988b).

Biotic variables, especially herbivory, may also strongly affect this process (Horsley and Marquis 1982, Whitney 1990, Peterson and Pickett 1995). In our study area, the use of an exclosure confirmed that deer browsing is not an important factor in this forest (S. CooperEllis and D. Foster, unpublished data). However, in the Tionesta old-growth area studied by Peterson and Pickett (1995), a 50-yr period of overgrazing eliminated most advance regeneration (Whitney 1990) and exerted a strong impact on succession after blowdown (Peterson and Pickett 1995; D. Foster, personal observation).

\section{Patterns and controls on forest damage}

The intensity, types, and mechanisms of wind damage require analysis because they control the size of canopy opening, the range of microsites produced, mortality and regeneration patterns, and the predictability of vegetation response (Brokaw and Walker 1991, Bellingham et al. 1995). The experiment enabled us to separate direct and indirect damage and to confirm that $<40 \%$ of trees damaged were directly pulled, and that indirect damage preferentially affected smaller stems $(<20 \mathrm{~cm} \mathrm{dbh})$. Overall, damage type was strongly influenced by species, size, and canopy position. Nearly $95 \%$ of Quercus rubra uprooted, whereas Acer rubrum individuals were more evenly distributed among uprooted, snapped, and bent categories. These species differences are partly explained by biomechanical variation: oak has stronger wood and less bole decay, and is therefore less likely to break than is Acer (J. Bertram, unpublished data). However, size is also a factor: Quercus rubra dominated the overstory, but Acer rubrum was important in the subcanopy and understory, where it was crushed, rather than uprooted, by falling trees. Among the Betula species, uprooting varied with canopy position and size, which were controlled by shade tolerance. Intolerant Betula papyrifera was restricted to the canopy; individuals were larger and nearly all were uprooted. More tolerant Betula lenta and B. alleghaniensis were more common in lower strata and, consequently, were more prone to snapping, bending, and leaning. 

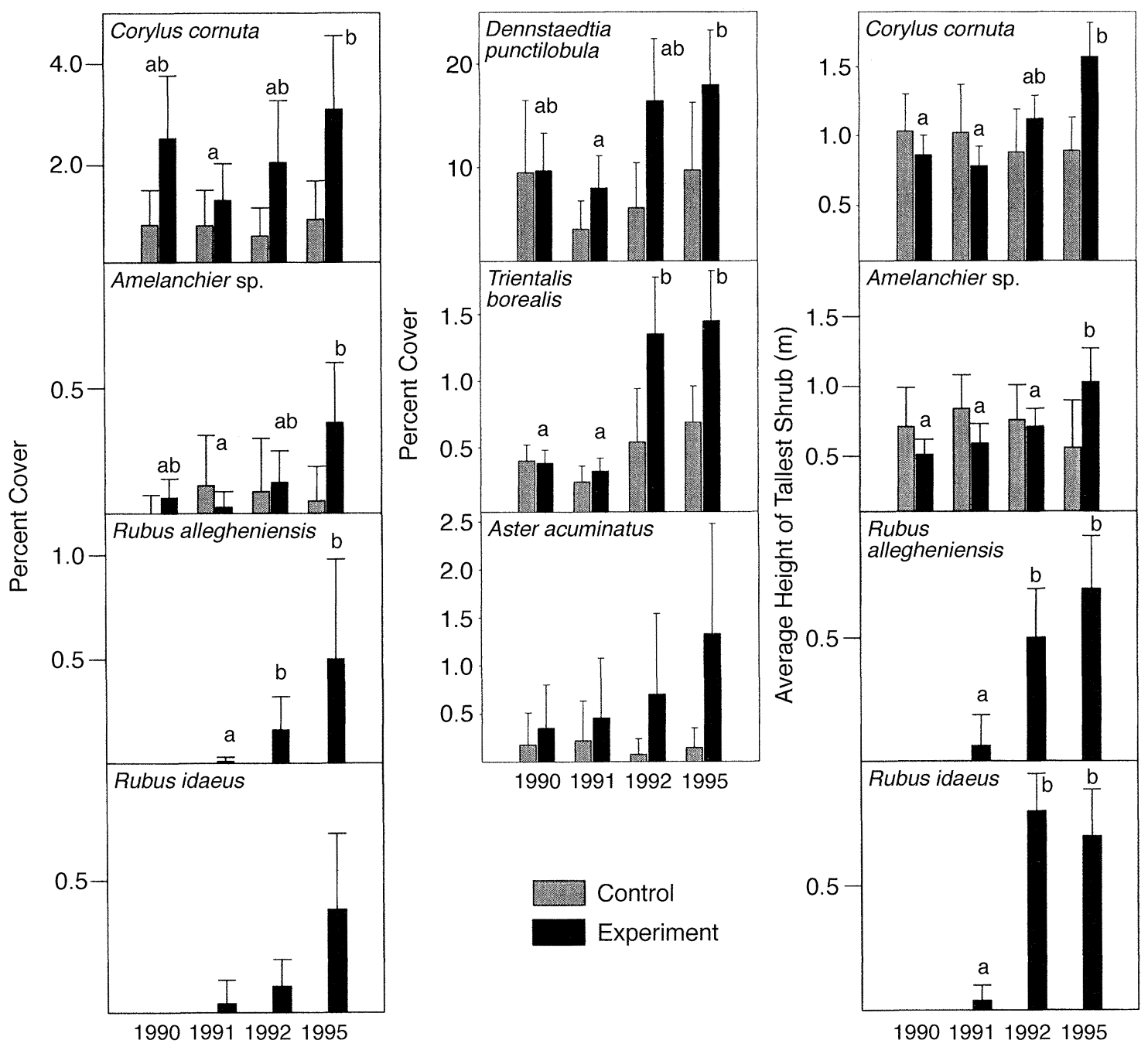

FIG. 7. Average percent cover of herb and shrub species and average height of tallest shrubs in the experiment and control before (1990) and after $(1991,1992,1995)$ the experiment, for species that changed. Error bars show 95\% confidence intervals. Within each panel, experiment means (solid bars) that do not share the same lowercase letter differ significantly $(P<0.05)$.

\section{Implications}

The results of this study may have consequences for the way we interpret disturbance and forest recovery and the way we manage forests. From a management perspective, this experiment yields a cautionary note. The disorderly appearance, concern over fire or pathogen outbreak, and interest in financial recovery often prompt immediate salvage logging on wind-damaged sites. However, our results indicate that the downed and damaged trees play an important role in forest recovery and ecosystem resilience. Logging kills the aboveground portions of the trees, eliminates leaf and woody biomass, decreases evapotranspiration, scarifies the soil surface, increases insolation, and damages many soil and organic structures created by disturbance (Brake and Post 1941). These impacts reduce biotic control over microenvironments, increase the potential for biogeochemical and hydrological change and nutrient loss, enhance the role of seedling establishment in regeneration, and promote compositional change (Bormann and Likens 1979). Thus, the potential exists to convert the damaged area from a relatively intact system to a strongly modified site in which ecosystem control is reduced (Foster et al. 1997). Although studies have indicated fairly rapid restoration of biotic control on intensive logging operations (Bormann et. al. 1974, Boring et. al. 1981), this study suggests that retention of the residual biotic structures in the disturbed forest yields a stronger degree of control, with very different vegetational consequences. Consequently, efforts to limit wind damage through management for wind-firm, diverse forests may be preferable to salvage, after the fact (O'Connor 1995).

Indirectly, this study reveals elements that are miss- 
TABLE 4. Understory composition for herbs and shrubs in the experimental area before (1990) and after $(1991,1992$, 1995) the manipulation.

\begin{tabular}{|c|c|c|c|c|}
\hline \multirow[b]{2}{*}{ Species $\dagger$} & \multicolumn{4}{|c|}{ Percent cover $\ddagger$} \\
\hline & 1990 & 1991 & 1992 & 1995 \\
\hline Lycopodium clavatum & + & & & \\
\hline Lycopodium lucidulum & + & & & \\
\hline Polygonatum pubescens & 0.1 & + & & \\
\hline Vitis sp. & + & + & & \\
\hline Goodyera pubescens & + & + & + & \\
\hline Celastrus scandens & & + & & \\
\hline Cirsium sp. & & + & & \\
\hline Houstonia caerulea & & + & & \\
\hline Hypericum punctatum & & + & & \\
\hline Pycnanthemum sp. & & + & & \\
\hline Erechtites hieracifolia & & + & + & \\
\hline Eupatorium sp. & & + & + & \\
\hline Hydrocotyle americana & & + & + & \\
\hline Lobelia inflata & & + & + & \\
\hline Luzula multiflora & & + & + & \\
\hline Epilobium coloratum/ciliatum & & + & + & + \\
\hline Potentilla simplex & & + & $(+)$ & 0.1 \\
\hline Rhus radicans & & + & + & + \\
\hline Rhus typhina & & + & + & + \\
\hline Rubus allegheniensis & & + & 0.2 & 0.5 \\
\hline Rubus idaeus & & 0.1 & 0.1 & 0.4 \\
\hline Solidago caesia & & + & $(+)$ & + \\
\hline Pteridium aquilinum & & & 0.1 & 0.2 \\
\hline Lonicera morrowii & & & & 0.1 \\
\hline Solidago rugosa & & & & 0.2 \\
\hline
\end{tabular}

Notes: Species present in all years were: Amelanchier cf. canadensis, Amphicarpa bracteata, Aralia nudicaulis, Arisaema triphyllum, Aster acuminatus, A. divaricatus, Athyrium felix-femina, Berberis thunbergii, Brachyelytrum erectum, Clintonia borealis, Corylus cornuta, Crataegus sp., Dennstaedtia punctilobula, Diervilla lonicera, Dryopteris carthusianalintermedia, Gaultheria procumbens, Ilex verticillata, Lonicera canadensis, Lycopodium obscurum, Lysimachia quadrifolia, Maianthemum canadense, Medeola virginiana, Mitchella repens, Onoclea sensibilis, Osmunda cinnamomea, $O$. claytoniana, Prenanthes sp., Rhododendron nudiflorum, Rubus hispidus, Smilacina racemosa, Smilax herbacea, Thelypteris nova-boracensis, Trientalis borealis, Uvularia sessilifolia, Vaccinium angustifolium, V. corymbosum, Viburnum acerifolium, V. cassinoides, V. recognitum, Viola blanda.

$\dagger$ Most graminoids are not included.

$\mp$ In most cases, cover is based on only one or two occurrences: + indicates species present at $<0.1 \%$ cover; $(+)$ indicates species probably present but missed in sampling.

ing from the modern New England landscape, despite its extensive disruption by the 1938 hurricane. The experimental manipulation produced abundant downed wood and tip-up mounds, and many leaning, bent, or malformed trees, some lying prostrate along the ground with a new vertical stem. These features are uncommon in the modern New England landscape and are generally restricted to sites that were not salvaged in 1938. Salvage and 60 years of subsequent logging have selectively removed many downed and malformed trees and have destroyed tip-up mounds and other features. Under natural conditions, a landscape subjected to infrequent intensive winds would be replete with these growth forms and structures.

Finally, this study offers new interpretations of disturbance and forest recovery. The characterization of the disturbance simulated by this experiment is strongly determined by which ecological parameter we observe. In terms of forest structure, standing biomass, and visual impacts, damage to the experimental area was catastrophic. The high survival and sprouting rate, however, led to minimal compositional change and a high degree of biotic regulation over ecosystem processes. In terms of these latter parameters, the disturbance was not severe. Other, less obvious disturbances such as climate change, atmospheric pollution, or pathogens may result in much greater disruption of forest ecosystems (Foster et al. 1997).

\section{Evaluating the simulation of a hurricane}

Our hurricane manipulation used a number of approaches to maximize similarity to a natural event: timing with peak hurricane season, selection of trees and direction of force based on empirical data, avoidance of mechanical damage to soils or trees, and creation of a large canopy opening ( $0.8 \mathrm{ha}$ ) involving many hundreds of trees in order to greatly exceed the scale of a single-tree gap.

The ecological impacts of the manipulation parallel many from the 1938 hurricane on which it was modeled. The percentage of damaged trees and damage distribution among size classes fall within the range for mature hardwood forests on exposed sites in 1938 (Rowlands 1941, Foster 1988a). The orientation of downed trees, the distribution of woody debris, and the range of new microsites produced a complex forest floor environment similar to that in 1938 (Foster 1988b). Biological structures such as leaning and bent trees, broken saplings and subcanopy trees with broken crowns, and resprouting uprooted and damaged trees are all a natural consequence of a hurricane. The manipulation is therefore an improvement over plot-sized experiments created using smaller equipment, tree cutting, or bulldozer (Collins and Pickett 1987, Sipe and Bazzaz 1995).

The simulation did have some limitations. Although we used a control and compared observations with a second, smaller manipulation (Carlton 1993), we did not achieve true replication (Hurlbert 1984, Schindler 1998). Meteorological conditions of intense precipitation and winds that strip leaves were not simulated. However, the experiment occurred within two weeks of leaf fall, and all but the tallest overstory trees received damage to branches and crowns. Despite its large size, the canopy gap was also smaller than many patches produced in 1938 (Foster 1988a). Although hurricane patterns do include small areas of relatively homogenous damage similar to our manipulation (Foster and Boose 1994), the abrupt transition between the experiment and buffer are more like a tornado blowdown. Despite these limitations, the large manipulated area enabled us to measure many attributes of hurricane impact within a dramatically reorganized environment (Bowden et al 1993, Carlton 1993). 


\section{ACKNOWLEDGMENTS}

This study was greatly assisted by the efforts of J. Bartee, R. Bowden, J. Carlson, W. Cass, K. Chamberlin, S. Cole, S. Dewalt, E. Doughty, J. Edwards, M. Fluet, the Harvard Forest Woods Crew, T. Jacobson, K. Keith, M. Kennon, T. Korsgren, K. LeClair, M. Leneway, R. Lent, K. McCarthy, J. McLachlan, P. Micks, S. Neelon, J. Quisel, N. Rajakaruna, T. Sipe, B. Slater, W. Smith, P. Yao, and Dennis Moran, Daniel Pepin, and equipment from the University of Massachusetts Forestry Crew. The study was initiated through collaboration with J. Aber, F. Bazzaz, J. Mellilo, and P. Steudler. Helpful suggestions were provided by J. S. Clark, J. Fuller, G. Motzkin, J. O'Keefe, D. Orwig, C. J. Peterson, A. Barker and two anonymous reviewers. Support came from the National Science Foundation (DEB 88 and 94-11975 and BIR-9300219) and the A. W. Mellon Foundation. This paper is a contribution from the Harvard Forest Long Term Ecological Research Program.

\section{Literature Cited}

Barten, P. K., T. Kyker-Snowman, P. J. Lyons, T. Mahlstedt, R. O'Connor, and B. A. Spencer. 1998. Managing a watershed protection forest. Journal of Forestry 96:10-15.

Baskin, C. C., and J. M. Baskin. 1996. Role of temperature and light in the germination ecology of buried seeds of weedy species of disturbed forests. II. Erectites hieracifolia. Canadian Journal of Botany 74:2002-2005.

Bazzaz, F. 1996. Plants in changing environments: linking physiological, population, and community ecology. Cambridge University Press, Cambridge, UK.

Bellingham, P. J., E. V. J. Tanner, and J. R. Healey. 1995. Damage and responsiveness of Jamaican montane tree species after disturbance by a hurricane. Ecology 76:25622580.

Boose, E. R., E. F. Boose, and A. L. Lezberg. 1998. A practical method for mapping trees using distance measurements. Ecology 79:819-827.

Boose, E. R., D. R. Foster, and M. Fluet. 1994. Hurricane impacts to tropical and temperate forest landscapes. Ecological Monographs 64:369-400.

Boring, L. R., C. D. Monk, and W. T. Swank. 1981. Early regeneration of a clear-cut southern Appalachian forest. Ecology 62:1244-1253.

Bormann, F. H. and G. E. Likens. 1979. Catastrophic disturbance and the steady state. American Scientist 67:660669.

Bormann, F. H., G. E. Likens, T. G. Siccama, R. S. Pierce, and J. S. Eaton. 1974. The export of nutrients and recovery of stable conditions following deforestation at Hubbard Brook. Ecological Monographs 44:255-277.

Boucher, D. H., J. H. Vandermeer, M. A. Mallona, N. Zamora, and I. Perfecto. 1994. Resistance and resilience in a directly regenerating rainforest: Nicaraguan trees of the Vochysiaceae after Hurricane Joan. Forest Ecology and Management 68:127-136.

Bowden, R. D., M. S. Castro, J. M. Melillo, P. A. Steudler, and J. D. Aber. 1993. Fluxes of greenhouse gases between soils and the atmosphere in a temperate forest following a simulated hurricane blowdown. Biogeochemistry 21:6171.

Brake, R. W., and H. A. Post. 1941. Natural restocking of hurricane damaged "old-field" white pine areas in north central Massachusetts. Thesis. Harvard University, Cambridge, Massachusetts, USA.

Brokaw, N. V. L., and L. R. Walker. 1991. Summary of the effects of Caribbean hurricanes on vegetation. Biotropica 23:442-447.

Canham, C. D. 1988. An index for understory light levels in and around canopy gaps. Ecology 69:1634-1638.

Carlton, G. C. 1993. Effects of microsite environment on tree regeneration following disturbance. Dissertation. Harvard University, Cambridge, Massachusetts, USA.

Carlton, G. C., and F. A. Bazzaz. 1998a. Resource congruence and forest regeneration following an experimental hurricane blowdown. Ecology 79:1305-1319.

Carlton, G. C., and F. A. Bazzaz. 1998b. Regeneration of three sympatric birch species on experimental hurricane blowdown microsites. Ecological Monographs 68:99-120.

Collins, B. S., and S. T. A. Pickett. 1987. Influence of canopy opening on the environment and herb layer in a northern hardwoods forest. Vegetatio 70:3-10.

Dunn, C. P., G. R. Guntenspergen, and J. R. Dorney. 1983. Catastrophic wind disturbance in an old-growth hemlockhardwood forest, Wisconsin. Canadian Journal of Botany 61:211-216.

Dunwiddie, P., D. Foster, D. Leopold, and R. T. Leverett. 1996. Old-growth forests of southern New England, New York, and Pennsylvania. Pages 126-143 in M. B. Davis, editor. Eastern old-growth forests: prospects for rediscovery and recovery. Island Press, Washington, D.C., USA.

Everham, E. M., and N. V. L. Brokaw. 1996. Forest damage and recovery from catastrophic wind. Botanical Review 62: $113-185$.

Foster, D. R. 1988a. Species and stand response to catastrophic wind in central New England, U.S.A. Journal of Ecology 76:135-151.

- 1988b. Disturbance history, community organization and vegetation dynamics of the old-growth Pisgah Forest, southwestern New Hampshire, U.S.A. Journal of Ecology 76:105-134.

Foster, D. R., J. D. Aber, J. M. Melillo, R. D. Bowden, and F. A. Bazzaz. 1997. Temperate forest response to natural catastrophic disturbance and chronic anthropogenic stress. BioScience 47:437-445.

Foster, D. R., and E. R. Boose. 1992. Patterns of forest damage resulting from catastrophic wind in central New England, USA. Journal of Ecology 80:79-98.

Foster, D. R., and E. R. Boose. 1994. Hurricane disturbance regimes in temperate and tropical forest ecosystems. Pages 305-339 in M. P. Coutts and J. Grace, editors. Wind and trees. Cambridge University Press, Cambridge, UK.

Foster, D. R., M. Fluet, and E. R. Boose. 1999. Human or natural disturbance: landscape dynamics in the tropical forests of Puerto Rico. Ecological Applications 9:555-572.

Hibbs, D. E. 1983. Forty years of forest succession in central New England. Ecology 64:1394-1401.

Horsley, S. B., and D. A. Marquis. 1982. Interference by weeds and deer with Allegheny hardwood reproduction. Canadian Journal of Forest Research 13:61-69.

Hurlbert, S. H. 1984. Pseudoreplication and the design of ecological field experiments. Ecolological Monographs 54: 187-211.

Livingston, R. B., and M. L. Allessio. 1968. Buried viable seed in successional field and forest stands, Harvard Forest, Massachusetts. Bulletin of the Torrey Botanical Club 95: 58-69.

Lyford, W. H., J. C. Goodlett, and W. H. Coates. 1963. Landforms, soils with fragipans, and forest on a slope in the Harvard Forest. Harvard Forest Bulletin Number 23. Harvard Forest, Petersham, Massachusetts, USA.

Magill, A., H. J. D. Aber, J. J. Hendricks, R. D. Bowden, J. M. Melillo, and P. A. Steudler. 1997. Biogeochemical response of forest ecosystems to simulated chronic nitrogen deposition. Ecological Applications 7:402-415.

Marks, P. L. 1974. The role of pin cherry (Prunus pensylvanica $\mathrm{L}$.) in the maintenance of stability in northern hardwood ecosystems. Ecological Monographs 44:73-88.

Merrens, E. J., and D. R. Peart. 1992. Effects of hurricane damage on individual growth and stand structure in a hard- 
wood forest in New Hampshire, USA. Journal of Ecology 80:787-795.

O'Connor, R. 1995. Quabbin Watershed: MDC Land Management Plan 1995-2004. Metropolitan District Commission, Commonwealth of Massachusetts, Boston, Massachusetts, USA.

Oliver, C. D., and B. C. Larson. 1990. Forest stand dynamics. McGraw Hill, New York, New York, USA.

Pacala, S. W., C. D. Canham, J. Saponara, J. A. Silander, Jr., R. K. Kobe, and E. Ribbens. 1996. Forest models defined by field measurements: II. Estimation, error analysis and dynamics. Ecological Monographs 66:1-43.

Peterson, C. J., and W. P. Carson. 1996. Gerneralizing forest regeneration models: the dependence of propagule availability on disturbance history and stand size. Canadian Journal of Forest Research 26:45-52.

Peterson, C. J., and S. T. A. Pickett. 1991. Treefall and resprouting following catastrophic windthrow in an oldgrowth hemlock-hardwoods forest. Forest Ecology and Management 42:205-217.

Peterson, C. J., and S. T. A. Pickett. 1995. Forest reorganization: a case study in an old-growth forest catastrophic blowdown. Ecology 76:763-774.

Rice, W. R. 1989. Analyzing tables of statistical tests. Evolution 75:1491-1502.

Rowlands, W. 1941. Damage to even-aged stands in Petersham, Massachusetts by the 1938 hurricane as influenced by stand condition. Thesis. Harvard University, Cambridge, Massachusetts, USA.

Schindler, D. W. 1998. Replication versus realism: The need for ecosystem-scale experiments. Ecosystems 1:323-334.

Simmons, C. S. 1939-1940. Soil survey of Harvard Forest. Harvard Forest Archives, Harvard Forest, Petersham, Massachusetts, USA.

Sipe, T. W., and F. A. Bazzaz. 1995. Gap partitioning among maples (Acer) in central New England: survival and growth. Ecology 76:1587-1602.

Spurr, S. H. 1957. Local climate in the Harvard Forest. Ecology 38:37-46.

Steinberg, D., and P. Colla. 1991. LOGIT: A supplementary module for SYSTAT. SYSTAT, Evanston, Illinois, USA.

Walker, L. R., J. Voltzow, J. D. Ackerman, D. S. Fernandez, and N. Fletcher. 1992. Immediate impact of Hurricane Hugo on a Puerto Rican rain forest. Ecology 73:691-694.

Webb, S. L. In press. Disturbance by wind in temperate zone forests. Pages 237-268 in L. Walker, editor. Ecosystems of disturbed ground. Elsevier, Amsterdam, The Netherlands.

Whitmore, T. C. 1982. On pattern and process in forests. Pages 45-59 in E. I. Newman, editor. The plant community as a working mechanism. Blackwell Scientific, Oxford, UK.

Whitney, G. G. 1990. The history and status of the hemlockhardwood forests of the Allegheny plateau. Journal of Ecology 78:443-458.

Zen, E. 1983. Bedrock geologic map of Massachusetts. Map scale 1:250 000. United States Geological Survey, Reston, Virginia, USA. 